\title{
'PROTESTANT' POLITICAL THEORY AND THE SIGNIFICANCE OF RIGHTS
}

\section{Sean Coyle, Reader in Jurisprudence, University College London*}

Modern political thought might be presented as a tension between two competing ideals: first, the notion of a community as a form of moral association which establishes and protects individuals' interests through representative politics and collective mechanisms of enforcement (which I shall refer to as 'idealism'); and, second, the idea of society as a dog-eat-dog world in which the private pursuit of wealth and happiness is constrained by rules and standards operating for the benefit of all (which I shall call 'positivism'). The notion of a right is central to both of these ideals, and it is plausible to see theories of rights as offering differing understandings of the significance of the modern polity's attachment to liberal values. The notion of a 'right' is of enormous significance for the liberal polity. Modern jurisprudential thought distinguishes two rival theories of rights, known as the Will theory and the Interest theory. My aim in this essay is to defend the Will theory of rights. Jurisprudential theories of rights are often presented as analytical attempts to clarify the essential nature of legal rights. The present essay represents a departure from this tradition: it is my aim to suggest that, far from constituting a dispute about the proper analysis of a concept, the Will and Interest theories represent fundamental yet conflicting ideologies which each throw differing light on our form of political association.

\section{Two Traditions of Political Reflection}

"[T]here is one kind of good that is so called in an absolute sense, and there is another that is good from the standpoint of a particular individual. Indeed, to borrow Aristotle's admirable explanation, 'Whatever each person's understanding has ruled for him regarding a given matter, that to him is good.' For God created Man ... 'free and sui iuris', so that the actions of each individual and the use of his possessions were made subject not to another's will, but to his own ... For what is that wellknown concept 'natural liberty' other the power of an individual to act in accordance with his own will?"

This passage of early modern political theory, and others like it, represents a crossroads in political thought. Having shaken off medieval assumptions concerning the association of the divine with the mundane, the idea began to take shape in the writings of Grotius and his contemporaries, that a form of life might be related to general ideas of natural law through the development of customary principles and forms of action which arise in response to

\footnotetext{
* I would like to thank Matthew Kramer, George Letsas and Amanda PerreauSaussine for their helpful comments and suggestions, as well as participants at a seminar in Queen's University Belfast where some of the arguments herein were presented.

1 Grotius, De Iure Praedae Commentarius [1604] (Oxford, Clarendon Press 1950), 18.
} 
particular problems of communal living. Reflection on our moral life, then, is not simply a matter of reporting the content of such customs and forms of action, but it is nevertheless rooted in those forms of action. The willingness of Grotius and his contemporaries to recognise distinct forms of the good constitutes a form of moral Protestantism the effects of which are with us still. For, on the one hand, we are accustomed to thinking of our political arrangements and social practices as being open to criticism in the light of moral standards which, in some sense, transcend those practices; and, on the other hand, we tend to view such critical standards as a matter of irresolvable disagreement and subjective understanding. These thoughts present us with conflicting views about the nature of moral insight: morality might be understood as a set of standards and principles which exist apart from the historically extended practices to which they apply, or as something fundamentally rooted in reflection on the here and now. The political theory of the modern day might then be thought of as the attempt to reconcile these divergent views about the source of moral insights with the thought that morality embodies standards and interests which make sense only within a system of collective practices.

The history of political thought has tended to emphasise two distinctive responses to the problems posed by moral Protestantism. One way of bringing the complexities of politics within the scope of general moral principles is to view politics as the earthly realm in which eternal values are applied and enforced. We can refer to this understanding of political life as 'moral idealism', or simply, 'idealism'. Political values, on this view, are the concrete manifestation of general moral demands, rather than a distinct kind of demand brought about by conditions of scarcity, need and inexhaustible desire. Insofar as morality concerns interests that are held and asserted within the context of shared social practices, the political life of the polity must be geared towards the resolution and protection of clashing interests according to standards of moral rightness which transcend the understandings which individuals bring to the identification of their interests and claims. Alternatively, the political realm might be represented as a domain of clashing interests which can be regimented in various possible ways: moral standards function not only within a pure realm of abstract thought, but also within the real world of social tensions and conflicting demands. Politics is then a matter of constructing and testing those possibilities. We can refer to this second view as 'positivism'. ${ }^{2}$ Rather than constituting a continuous intellectual realm, morality and politics can be construed as defining separate yet overlapping intellectual domains, in which political values represent generalised responses to the variable conditions of collective living, offering makeshift solutions to the problem of continually shifting desires and perpetually clashing interests. Customary norms and forms of redress may then evolve in response to shared expectations, but we might regard those forms of redress as being related to general moral norms only broadly and indirectly.

2 I do not, of course, mean to refer to the view that there are no 'necessary connections' between law and morality, or to the view that law consists only in rules which have been deliberately laid down by some recognised authority. Positivism in this sense nevertheless has obvious and important connections with more familiar views which go by that name. 
The notion of a 'right' is central to both approaches. The implications of these connections may, however, be traced out in different ways. For, on the one hand, it is possible to conceive of rights as establishing and protecting individual interests (the 'Interest theory'), and on the other, rights might be viewed as securing individual freedom from collective control, through the establishment of protected choices (the 'Will theory'). Initially, at least, we might be led to assume that such distinctions are of no significance to the distinction between positivist and idealist views of the polity.

The idealist views the legal order as outlining principles of justice which apply mutatis mutandis to all citizens, who stand in social relationships requiring systematic expression. We might view the idealist notion of rights as one in terms of which an individual's rights are determined on the basis of general principles which underpin the polity's aggregative and distributive goals. We will then view rights as embodying interests defined on the basis of judgments about the common good. Alternatively, idealists might conceive of individual rights as mapping out conjointly possible domains of autonomy in which individuals are free to pursue their own interests in their own way. Judgments as to the extent of individual rights would then be a matter of determining which exercises of choice are compatible with similar exercises of choice on the part of others on the basis of principles of equal freedom: rights, on this view, constitute protected choices rather than legally established interests.

Positivists, by contrast, view the doctrinal categories of the law in a more limited way, as outlining a series of rules and principles which achieve a reasonable balance between competing interests and which establish powers through which individuals can make normatively significant choices about their relationships with other people. The focus of the positivist account is therefore not upon the articulation of general principles which apply as political standards to all, but on the delineation of rules which provide a framework for social interaction, and on the interstices between the rules within which individuals may pursue interests and exercise choices.

Despite the possibility of such connections between positivism, idealism and the notion of a right, there are good reasons for disputing the suggestion that the distinction between protected interests and protected choices has no significance for the political ideals represented by positivism and idealism. Indeed, my arguments will seek to establish that the notion of protected interests is central to the possibility of liberal forms of idealism, and that positivism is best understood in association with the protection of individual choice. One reason why the idea of a 'right' might be thought to have no intrinsic significance for debates about the nature of the polity is that the jurisprudential analysis of rights is thought to highlight different ways in which our conceptual intuitions about the ordinary use of the word 'right' might be regimented: by, for example, denying that children can correctly be said to possess rights, or by suggesting that rights reflect public standards of conduct (within the criminal law, say) as well as private choices. Because no political issues are predetermined by such definitional preferences, it is thought, the notion of a right embodies a set of conceptual ideas which 
remain separate from broader political ideals. ${ }^{3}$ This, I shall argue, is a mistake.

\section{Suggestive Connections}

The Will and Interest theories represent opposing conceptions of the social framework within which political projects are formulated and carried out. For they offer radically different interpretations of the purpose of our form of political association, and of law's role in shaping that form of association. If the life of the modern state embodies a 'Protestant' view of political theory, then the notion of a right is central to our understanding of that life. ${ }^{4}$ Yet neither Protestantism, nor the idea of rights, is inevitable wherever law emerges as a distinctive force in the political realm. The laws of ancient Greece, for example, were geared towards the pursuit of excellence and of rules bringing about conditions which make excellent, valuable lives possible, rather than to the establishment of rules promoting sectional interests or autonomy. Even within medieval common law scholarship, the law was conceived in terms of the reasoned settlement of wrongs, without any parallel notion of individual rights as we have come to understand the term.

The history of the idea of rights is accordingly an important and instructive one as far as the dynamics and tensions of modern political thought are concerned, and of attempts to understand the place of law within its peculiar currents. The language of rights comes to us from Roman law, and its origins lie in the word ius..$^{5}$ The dominant usage among the Roman jurists treated ius as signifying something objectively right or just, and in this way it functioned as a synonym for 'law' as long as the dominant legal treatises

3 See e.g. MH Kramer, 'Rights Without Trimmings' in Kramer, Simmonds \& Steiner, A Debate Over Rights: Philosophical Enquiries (Oxford, Clarendon Press 1998). The attribution or denial of rights to children is thus a formal consequence of the definition of a right as a protected interest or choice, and leaves undisturbed the question of the extent to which the law ought to protect the interests or choices of children. Similarly, the argument about whether the criminal law confers individual rights involves no disagreement about which forms of behaviour should be classified as crimes (or of the consequences of such classifications), but rather reflects a disagreement over the conceptual distinction between public and private law.

4 The combined centrality and irreconcilability of the Will and Interest theories might help to explain the tendency of some jurisprudential writers to engage in attempts to 'move beyond' those theories, or to suggest that the Will and Interest theories are not jointly exhaustive of the domain of rights. (See for example R Cruft, 'Rights: Beyond the Interest Theory and the Will Theory?' 23 Law and Philosophy (2004) 347-97, and W Lucy, 'Rights, Values and Controversy' V Canadian J of Law and Jurisprudence (1992) 195-213.) When viewed as a central tension in the political life of the state, however, such attempts to reconcile the Will and Interest theories come to resemble contrived and superficial exercises in presenting an inescapable political choice as a definitional controversy capable of being sidelined as an interesting though largely fruitless analytical problem.

5 More particularly, the origins of the notion of a 'right' lie in the complex and shifting relationship which existed between the concepts of ius, dominium and res. I do not propose to examine this relationship in any detail, but a brief yet informative account can be found in R Tuck, Natural Rights Theories: Their Origin and Development (Cambridge, Cambridge University Press 1979) ch.1. 
were composed in Latin. At the same time, the term was essential to claims about the way two disputants should behave towards one another, and was thus confined to the description of private, bilateral relationships. ${ }^{6}$ Both Grotius and his English counterpart, Thomas Rutherford, were conscious of these various dimensions to the word 'right': 'right' was said to signify, first and foremost, what is right and just; but it can also carry the sense of 'law', and it could also denote an individual moral faculty or power. ${ }^{7}$ This ambiguity in the notion of a 'right', which could function as an objective claim about justice or a subjective appeal for justice, can be seen as the defining problem for modern political theory. For once we are in possession of the distinction between objective and subjective ius, the notion of objective right can be conceived as a fixed standard against which the inequalities and imperfections of ordinary life can be measured. Hence it becomes easy to imagine that the ordinary, subjective claims individuals make in relation to their rights are ultimately governed by an ideal moral order of rightness. We might then hope that the constantly shifting pattern of uncoordinated and competing claims can be rationalised in a way which reflects that ideal order: then we will have simultaneously reconciled those clashing interests and delineated the scope of individuals' legitimate interests, or rights.

But for the positivist, who dismisses the possibility of reconciling the notions of objective and subjective right, the political life of the state will come to be regarded as a matter of achieving a reasonable and stable balancing of those interests. Rights will then take on a different role: for if no stable perspective exists against which the irregularities and conflicts of everyday life can be evaluated and resolved, individual rights will come to play a central role in the delineation of protected spheres of interest and choice distinct from the aggregative and distributive policies of the state. The laws of the polity will accordingly resemble less a body of principles aiming at the establishment and protection of equal rights, and more a framework of social rules for dealing with the effects of manifest inequalities. To that extent, the law can be seen as displaying a concern with the needs and wants of individuals, and as securing a framework of stable expectations in which those needs and wants can be pursued and fulfilled.

The notions of ius, dominium and res had been the subject of technical debates by the Roman jurists for centuries. But while such arguments were a vital part of the theoretical underpinnings of Roman law, they did not figure greatly in the day-to-day applications of that law. Ideas of right appeared in the guise of general juridical assumptions rather than as weapons to be wielded in the course of Roman litigation. The circumstances of early modern Europe were nevertheless to propel those ideas and assumptions onto the centre stage of political and legal thought where, in effect, they have remained.

The collapse of medieval beliefs which linked governance and authority with the divine order left in its wake a series of assumptions about human equality. Natural lawyers such as Grotius had shown that long-established

6 ibid., 8.

7 See Grotius, De Iure Belli ac Pacis [1625] I.1.iii-ix. Rutherford echoes Grotius in his Institutes of Natural Law [1754] Book 1, ch.2, 25-33. 
social roles were not the reflection of some higher natural order, but rather one of a number of social forms which might be 'patterned after nature's plan'. ${ }^{8}$ Forms of political authority were thus to be construed as productions of the human will which attempted to give expression to mankind's essentially social nature: in the absence of such social forms, individuals confronted one another as fundamental equals. A new conception of the significance and purpose of political society emerged, not as a natural means of upholding divinely ordained values, but as a form of association in which every person's interests could be peacefully coordinated and protected.

The natural lawyers and their positivist critics nevertheless construed the significance of this fresh insight into the political realm in very different ways. On the one hand, the natural lawyers viewed the purpose of political reflection as involving the working out of the ideal form of society, in which man's natural equality is respected and enhanced. The legal life of the polity consisted, for those jurists, in tracing out the structure of an ideal body of rights in terms of which individual interests are articulated, and the legitimate bounds of individuals' entitlements discovered. Individual rights were therefore conceived as essentially public standards, a matter for collective determination in the light of a shared conception of justice rather than for private choice. For positivists, on the other hand, the evaporation of universal moral norms signalled a right to determine the course of one's life in one's own way. For the joint pursuit of individual conceptions of the worthwhile life to emerge as a genuine possibility, however, each individual must be free in various respects from collective forms of control so that autonomous choices can be meaningfully formulated and exercised. On this view, the legal order is best represented not as a systematic body of rights rooted in some shared conception of the good, but rather as a body of rules acting as anchor-points for autonomous choice in a sea of ever-shifting political assumptions.

We can, in this way, view the idea of a 'right' as suggesting differing ways of dealing with the consequences of Protestant political thought. Those positivists who saw rights as defining areas of individual autonomy shielded from collective control developed theories of law which attempted to divorce juridical conceptions and arguments from wider matters of moral and political concern. The development of detailed doctrinal rules and principles in isolation from collective political introspection was seen as central to the possibility of individual rights. For it is only in the context of such stable practices that individuals can form reliable expectations which make possible the possession of meaningful control over aspects of their lives. The dependence of private law upon general recognition and collective enforcement meant that the realm of private entitlements could never be fully distinct from the aspirations and goals of the public sphere, but the creation of a comparatively stable set of rules which are relatively immune from direct pressure from shifting political attitudes was nevertheless felt to be the only meaningful way in which a society could give effect to the liberal ideal. But where rights are thought of as being rooted in interests rather than the will, the integrity of rights ceases to be a matter of the comparative stability and immunity of an individual's entitlements from revision in the light of

8 Grotius, above n.1, 229. 
principles of general political concern, and becomes a question of the integrity and consistency of a body of principles inherently and pervasively shaped by publicly determined standards and shared conceptions of the good. The liberal nature of society, then, is reflected in the view that questions of individual interest are a matter for joint interpretation and concern.

The positivist and idealist versions of Protestant political thought can be seen to reflect differing views of the liberal polity's commitment to liberal values. The foregoing reflections suggest one way in which these connections might be understood. Positivism is not inevitably associated with a focus on individual autonomy over a concern with individual interests, for we might view the task of law as that of achieving some reasonable balance between essentially competing interests. It is this thought which has led to the belief that positivism is equally compatible with the Interest theory as with the Will theory. Yet there are reasons for doubting the value of such connections: the interests which are established and protected by legal rules can be viewed as establishing rights only if we are willing to downplay the idea that the society's legal arrangements take the form of relatively fixed and stable rules. For where rights are defined in terms of protected interests, such rights are not merely the fixed and stable products of the enactment of particular legal rules, but are central to the interpretation of a body of laws as a whole. Each rule will then be read as a partial attempt to trace out the relative boundaries of competing entitlements, so that rights and interests stand apart from and above the posited rules as such. The form of moral reasoning at work in such a conception is one in which rules are reduced to the status of mere guides to the content of rights and interests, which must be fleshed out according to the political or moral values which the rules serve; or else legal rules must be viewed as highly incomplete expressions of legal rights which leave much to be determined on the basis of extra-legal, moral and political ideas. ${ }^{9}$ Even where positivism is understood primarily as a set of beliefs about law's constitutive role in constructing the social world, its associations with the Interest theory might thus be seen as more superficial than its connections with the realisation and protection of liberty and choice.

Idealism is characterised by the belief that rights, rather than rules, constitute the basic elements in legal thought. The development of the Will theory suggested another way in which such thoughts could be given substance: rights might be seen as determining jointly possible domains of choice sustained by principles of autonomy which apply to all. Abstract principles of autonomy accordingly define the maximal set of freedoms which can exist conjointly with similar freedoms possessed by others. Since certain exercises of freedom will restrict (or bring to an end) the freedom of others, legal rules restricting individual freedom (such as the freedom to commit violent acts against the person) are justified insofar as they are necessary for

9 The latter approach is the one which has in fact commanded the attention of many recent positivist thinkers (thinkers as diverse as Jeremy Bentham, Neil MacCormick, Joseph Raz and Matthew Kramer). As my remarks no doubt imply, I remain uninterested in versions of positivism which consist simply in the proposition that law and morality are conceptually separate: I continue to believe that 'positivism', in the interesting sense of a body of relatively stable rules which are interpreted in relative isolation from wider moral and political currents of thought, does not sit well with forms of collective reflection. 
the realisation and preservation of freedom overall. ${ }^{10}$ This notion of a system of equal freedoms is, of course, a juridical fantasy: in a world of scarce resources and finite possibilities, my choices inherently impinge upon those of others, and a system of rules which seeks to impose uniform conditions of equal choice on a social world governed by uncoordinated wills and constantly shifting opportunities will be forced to seek for such conditions at ever increasing levels of abstraction. ${ }^{11}$ The emptiness of the idea of juridical equality rooted in the will has the consequence that only forms of idealism which represent rights as interests are capable of providing meaningful insights into Protestant political thought.

The notion of a 'right' is thus not a formal one which is devoid of important political commitments, but rather one which presupposes differing conceptions of our form of political association. The remainder of this essay will describe and chart some of these commitments.

\section{The Interest Theory and Liberal Equality}

Both the positivist approach and the liberal idealist approach run into problems. Where positivism is committed to the Will theory, it might be seen as condoning forms of radical conservatism which leave the realisation of important individual interests to market forces and the vagaries of representative political institutions. By using law to preserve and extend the private realm, does not the positivist threaten important individual interests and render minority oppression at the hands of the majority much more likely? Idealism, on the other hand, by construing rights directly in terms of interests, connects questions of social and political justice much more firmly and directly with the adjudicative process. Unlike the wider political process, in which each person's voice is drowned out by an ocean of similar voices, the adjudicative process is one in which each person's claims can be heard and evaluated specifically and directly. But the same conditions which make idealism an attractive philosophy of law also undermine the value and purpose of rights as the principal means through which individuals can assert and defend their interests. By threatening the integrity of private law as a body of principles distinct from general political debate, idealism casts into doubt the reality of blocks of private life marked off from public scrutiny and regulation.

The traditional conception of adjudication is one in which parties to a dispute submit pleas to the court and present reasoned arguments and proofs for a decision in their favour. ${ }^{12}$ It is this dimension of adjudication that lies at the centre of idealistic assumptions about the judicial process as a special and

10 The Kantian Will theory, e.g. was of this kind (see F Rosen, Kant's Theory of Justice (Ithaca, Cornell University Press 1993). For positivism's relationship with the Interest theory, see above n.8.

11 See Rosen, above n.10, and N Simmonds, 'Rights at the Cutting Edge' in Kramer, Simmonds \& Steiner, A Debate Over Rights: Philosophical Enquiries (Oxford, Clarendon Press 1998). For a recent attempt to rehabilitate the Kantian view, see H Steiner, An Essay on Rights (Oxford, Blackwell 1994), and a partial retraction in Steiner, 'Working Rights' in A Debate Over Rights, op. cit.

12 L. Fuller, 'The Forms and Limits of Adjudication' 92 Harvard L Rev (1978) 353, at 364. See also O. Fiss, 'The Forms of Justice' 93 Harvard L Rev (1979) 1. 
essential form of participation in legal decision-making through which individuals can directly articulate and protect their fundamental interests. In his impressive article 'On the Form and Limits of Adjudication', Lon Fuller presents an argument which we can see as constituting a devastating problem for idealism and the Interest theory. Fuller develops the idea of a 'polycentric' problem: a problem in which the solution depends upon the resolution of tensions within a complex web of relationships where '[a] pull on one strand will distribute tensions after a complicated pattern throughout the web as a whole.' ${ }^{13}$ Problems of this kind bear certain similarities to the behaviour of a spider web:

"Doubling the original pull will, in all likelihood, not simply double each of the resulting tensions but will rather create a different complicated pattern of tensions. This would certainly occur, for example, if the doubled pull caused one or more of the weaker strands to snap. This is a 'polycentric' situation because it is 'many-centred' - each crossing of strands is a distinct centre for distributing tensions." 14

Where rights are thought of as protecting interests, such problems are brought to the fore: for the parties to a case are regarded as asserting claims which depend not just upon the history and circumstances of the dispute between them, but upon broad and general principles which apply to all. An individual's rights thus appear in the guise of interests wielded and asserted in the context of complex patterns of similar and competing interests, delineated not simply by reference to established rules but according to broad conceptions of equality and the good. The 'legal' dimension to adjudication is then preserved by the representation of such overtly political concerns as elements in the construction of 'juridical equality'. Yet the presence of such political elements in juridical reasoning comprehensively undermines the driving insight that the judicial process offers individuals a direct means of defending their interests against outside intrusion. By requiring rights to be delineated in a broader context of competing political assumptions, rights function effectively only insofar as they conform to collective notions of what each individual's legitimate interests are. In such circumstances, the idea that adjudication furnishes individual litigants with meaningful control over their own interests is an empty form indeed.

Fuller believed that polycentric problems constitute the limits of effective adjudication. ${ }^{15}$ For in the context of clashing political values and ideals, the ability of the litigant to offer reasoned arguments and proofs is fatally undermined: the plaintiff cannot prove the existence of an entitlement, because such proofs presuppose the existence of a stable structure of rules and doctrines against which competing claims can be evaluated and tested. The possibility of offering reasoned arguments in favour of a given standpoint is similarly undercut, as the process of reasoning is one no longer

13 ibid., 395.

14 ibid.

15 Fuller's reasons differ rather considerably from mine, but his arguments might be seen as addressing parallel and perhaps wider concerns. There is a great deal in Fuller's careful treatment of polycentric problems which merits consideration. See Fuller, ibid., 394. 
rooted in a context of stable assumptions and accepted starting-points upon which the litigants' 'reasons' can focus. Rather than offering reasoned interpretations of established doctrines and principles, the party wishing to assert that a right has been infringed must orientate his claims within a context of political and moral thought where disagreement attaches not just to the interpretation of rules, but also to the question of what the permissible starting-points of the reasoning process are. Potentially intractable political and ethical dilemmas would then have been converted into legal questions which lie at the very heart of our doctrinal understandings. ${ }^{16}$

The Interest theory has a particularly powerful association with idealist modes of thought. For in making individual interests the focus of an account of rights, the Interest theorist is forced into thinking of rights as concerning not the autonomous decisions of individuals who make choices in the light of their own conceptions of their interests, but instead the general social context in which those choices are made. Since individuals disagree about their rights and interests, and since those disagreements arise from decisions made in the context of social conditions of scarcity, competition, cooperation, economic variability and ever-changing desires, rights come to be seen as a matter for collective decision as part of a political process in which other social goods are at stake. Interests become a matter of what individuals would recognise if they were free of the imperfections and inequalities (both advantageous and disadvantageous) which pervade their lives. The Interest theorist thus simultaneously places rights at the centre of political thought, and undermines the idea of a right as a stable and lasting form of protection whose exercise lies predominantly within the control of the right-holder rather than 'another's will'. ${ }^{17}$

Liberal idealism of this kind can plausibly be viewed as one way in which to work out the implications of a Protestant conception of political theory. The political thinking of the post-medieval world is shaped by the notion of individuals as both a focus for moral and political concern, and as sources of moral insight and reflection in relation to the good life. The erosion of religious belief as a source of shared insights and understandings, as well as the decline of the feudal order as a framework for the regulation of narrow and inherited social roles, forced the idea of conflicting individual claims into the limelight of political thought. The realm of politics was thus connected with morality in a much more complex way than medieval thought supposed: natural law came to be regarded not as a set of unchanging moral prescriptions identifying the good independently of concrete social arrangements, but as a body of broad principles capable of grounding agreement on general matters such as the desirability of social coexistence, whatever form such arrangements might take. More concrete moral insights arose, in Hume's words, 'from the circumstances and necessities of

16 One recent advocate of human rights-inspired idealism is openly circumspect about the possibility of proving rights claims: see F. Klug, Values For a Godless Age: The Story of the United Kingdom's New Bill of Rights (London, Penguin $2000), 18$. Such claims take place in the context of a 'debate without end' where understandings of rights shift in the light of changing moral, philosophical and political ideals.

17 Grotius, above n.1. 
mankind' about which different individuals might disagree. ${ }^{18}$ Thus, while goodness could not depend solely on the content of local customs and practices, it was no longer straightforwardly possible to hold up social arrangements to the blinding light of eternal and transcendent standards: moral ideas, though constituting standards of criticism for concrete social arrangements, could not be understood wholly apart from the history of social and political institutions. Idealism, then, reflected Hume's belief that 'Tho' rules of justice be artificial, they are not arbitrary.' ${ }^{19}$

Liberal idealism should be read as an attempt to tackle the consequences of moral Protestantism by displaying a concern with the general framework within which different individuals formulate and argue about their interests. The basic insight that plural visions of social and political good might coexist in a single social setting is thus recast as a concern with equality among individuals who realise that 'the issues of principle affecting them the people - should be settled, ultimately, by them and only them on a basis that paid tribute to their fundamental equality.' ${ }^{20}$ Rather than mapping out areas within which the exercise of distinctive visions is possible, rights come to be understood as the general, public standards which result from collective deliberation over differing moral visions:

"Integrity expands and deepens the role individual citizens can play in developing the public standards of their community because it requires them to treat relations among themselves as characteristically, not just spasmodically, governed by these standards . . . Political obligation is then not just a matter of obeying the discrete political decisions of the community one by one, as political philosophers usually represent it. It becomes a more Protestant idea: fidelity to a scheme of principle each citizen has a responsibility to identify, ultimately for himself, as his community's scheme."21

According to liberal idealism, then, rights mark out important interests in which every individual has a stake, and which result from collective reflection into the nature and characteristics of individual wellbeing as a

18 Hume, A Treatise of Human Nature, P.H. Nidditch trans. (New York, Oxford University Press 1978) 477.

19 ibid., 484. 'Artificial', in Hume's sense, referred to the adventitious conditions in which justice emerges, rather than to any sense of justice as determined by purely positive stipulation.

20 Waldron, Law and Disagreement (Oxford, Clarendon Press 1999) 249.

21 R. Dworkin, Law's Empire (London, Fontana Press 1986) 190. Dworkin has elsewhere elaborated on this idea: '[I]n my view, integrity is itself a dimension of equal respect. Indeed, in a community divided in moral and political judgment and instinct, it is a peculiarly important dimension of equal respect. We cannot expect of our fellow citizens, either as individuals or collectively in politics, that they treat us as we think justice on the right conception requires. But we can demand of ourselves and of them that we treat each other evenhandedly, that is, that we deny no one the respect we accord others according to our own convictions about what equal respect means. Law as integrity assumes that we can make sense of and enforce that demand collectively, in politics and adjudication, as well as individually. ..' 'Integrity, Equality and Respect: A Reply', Revue Internationale de Philosophie (2005) 40. 
source of interests. One might well wonder to what extent such a conception of political liberalism remains moored in the values of liberal pluralism from which the liberal tradition emerged. ${ }^{22}$ Leaving that consideration on one side, however, we may worry independently about the implications of such a view for understandings of the nature of legal reasoning. For the view of rights as interests defined in the light of some general notion of 'liberal equality' seems very far removed from the history and traditions of common law scholarship through which law's representation as a form of moral association is conceived and expressed.

The liberal equality approach compels us to look upon the law as a coherent expression of justice governed by categorical principles. The possibility of presenting legal rules and decisions as instances of more general principles and categories appears as no accidental consequence of academic scholarship, but as the result of a coherent moral vision running throughout the law. Law can be represented as a form of moral association, it is thought, precisely because it gives expression to a substantive moral ideal. The liberal credentials of the theory are preserved through the notion that the 'substance' of these moral ideas must be connected with jurisprudential understandings of the established rules and doctrines of the legal order, and that each person may 'fit' those substantive ideas to the rules and decisions in different ways. The reality of such connections is open to doubt: the idea of equality signifies nothing unless connected with specific situations which may be compared as equal or unequal in various respects. But the concept of equality itself can do very little to clarify which peculiar features of a case are 'relevant', so that there are potentially limitless ways in which various cases can be presented as embodying specific equalities or inequalities. Any theory which locates the law's moral nature in the idea of a substantive moral ideal is thus forced to justify general and inevitably contentious understandings of the nature of equality.

Faced with such difficulties, we might wonder why a substantive conception of the good is thought to be necessary to an understanding of law as a moral idea. The liberal ideal is one which gives each person a separate voice in the determination of social good. Liberals have thus tended to regard ideas of virtue as being rooted in the experiences and understandings of individual thinkers who possess the ability to reflect critically on their experience. Even if we can correctly assume that individuals in general possess the intellectual wherewithal to transcend their sectional interests in coming to an understanding of social good, the presence of uncontentious standpoints on matters such as equality and justified entitlement could only emerge as a contingent feature of moral experience. The idea of well-being in Protestant political thought comes to us not as some generalised idea which can be contemplated independently of individual wills and desires, but as something which can only be defined by each person in the light of one's own experiences and needs. It is perhaps the fact that individuals may develop openly distasteful, odd or destructive preferences which prompts the search for 'external' standards, anchored not in the circumstances of individual lives and choices but in some abstract realm of moral value. It is then tempting to regard a person's interests as a matter of what that person would recognise as

22 See N. Simmonds, 'Rights at the Cutting Edge', above n.11, at 129. 
being good for one if placed in appropriate conditions or blessed with certain insights into the rational or the reasonable. ${ }^{23}$ Might we not seek to explain the differences in the way each person values things by the presence of bias and ignorance brought about by purely environmental factors?

As Raymond Geuss has observed, liberal thinking is a form of thinking 'that needed to be embedded in a more encompassing form of reflection.' ${ }^{24}$ For liberalism is sustained by a Protestant ethic which views moral experience as fundamentally variegated and uneven. We can then perceive idealism as attempting to flatten out our moral life into a level perspective for the application of moral ideas to all; and as therefore constituting a shift away from a form of reflection in which liberalism can survive as a meaningful ideal. Judgments about what is in a person's interests become counterfactual judgments, ${ }^{25}$ which lead us to a reformulation of the central question of political theory: we ask not, 'how can each person's interests be reconciled with those of others?', but 'under what conditions is an individual's own assessment of one's situation definitive?' A person's entitlements will come to be regarded increasingly as a matter for collective determination and enforcement, rather than an individual's control over aspects of one's moral life.

The form of legal reasoning within the common law does not easily lend itself to such idealistic interpretations. Even the categorical divisions of Roman law, seen by the early modern jurists as the apogee of rational legal order, were never more than a heuristic aid for students of the common law despite the various attempts made during the course of the seventeenth and eighteenth centuries to offer Romanist explanations of the sources of law. ${ }^{26}$ It was perhaps the failure of such efforts to ground common law reasoning in general categorical principles that led Stair in 1681 to proclaim, somewhat disingenuously, that:

"there are not wanting of late of the learnedest lawyers, who have thought it both feasible and fit, that the law should be formed into a rational discipline, and have much regretted it hath not been effectuated, yea scarcely been attempted by any." 27

Such efforts at rationalisation of the law were, however, associated more with widespread dissatisfaction towards the rather cumbersome and irrational collection of rules and procedures which characterised the common law form of pleading than with any sweeping moral or political concern with the form of the legal order as a whole. It was thus with the clarification and simplification of writs and pleadings, rather than the desire to understand writs and pleadings as more mundane instances of some greater principle,

23 See the excellent discussion in R. Geuss, History and Illusion in Politics (Cambridge, Cambridge University Press 2001) ch.2.

24 ibid., 104.

25 ibid., 101.

26 Of these oft-repeated endeavours, perhaps the best known (though not the most successful) was that of Blackstone, principally in the beginning of Book I of his Commentaries: for an informative discussion see M. Lobban, The Common Law and English Jurisprudence 1760-1850 (Oxford, Clarendon Press 1991) ch.3.

27 Stair, Institutions of the Law of Scotland [1681], I.i.17. 
that common lawyers principally concerned themselves. The notion of a 'right' was thus something of political significance, but little legal importance, in the history of the common law. For the idea of a right to be meaningful, I have argued, it must operate within a context of fairly stable and precise rules through which rights are identified and delimited. Yet the idea of law as a system of identifiable rules is a relatively new one: until well into the nineteenth century, the common law was conceived principally in terms of remedies and procedures in which the courts could hear disputes and offer just solutions to any wrong which had been correctly presented. It was thus the form in which the wrong was presented to the court, rather than the establishment of juridical proofs which lay at the centre of legal thought. The law was viewed as a reasoning process channelled along strict lines governed by the system of writs. The reasoning involved was thus not source-based, but rooted in 'reason', understood in broad terms as a wise and reasonable approach to life. Judges could thus draw their deliberations from ordinary experience and common sense, as well as considerations of policy, philosophy and a pragmatic sense of what was convenient or justified in the circumstances. A legal action was defined as the lawful demand of one's right or due; 'yet this right was undefined in terms of rules. Right was only defined in the broadest sense. . .'28

Viewed in terms of the distinction between objective and subjective right (ius), such a notion of legal right is extremely difficult to pin down. Despite the obvious overtones of objective ius present in the notion of 'one's due', the common law possessed no conception of individual entitlements as defined in terms of general principles preceding the settlement of cases at law. The same ambiguity frustrates any attempt to cast this classical common law understanding of rights in terms of the distinction between the Will and Interest theories. The idea of demanding one's right involved outlining an interest which had been violated, and which merited a remedy in law. Such a view might seem to favour the Interest theory, since the basis of a legal claim did not essentially concern the exercise of individual powers over another's duties, but rather interests which had been harmed. The Will theory depends upon certain formal characteristics of the modern legal order: principally, it depends upon the conception of law as a body of rules and standards which identify an individual's obligations under the law, as well as relatively clear rules establishing areas of autonomy consisting in claims against interference or for assistance, liberties to engage in or refrain from certain actions, immunities against arbitrary changes to one's established entitlements as well as powers of control in relation to those entitlements. ${ }^{29}$ Lacking anything approaching these ideas, the classical common law could offer no basis for an understanding of rights as protected choices. Yet neither is there any real conformity with the notion of rights as constituting protected interests; for the procedural emphasis of the system of writs and pleadings made it impossible for plaintiffs to define their rights a priori in terms of established rules or principles. Plaintiffs did not enjoy claims to the

28 Lobban, above n.26, 62. I am much indebted to Lobban's book for its rigorous clarification of these sometimes confusing and contradictory aspects of postEnlightenment common law thought.

29 I refer, of course to Hohfeld's 'fundamental legal conceptions'. I examine each of these conceptions in more detail below. 
enforcement of their rights, but rather undertook actions for a remedy in respect of wrongs which had been done to them. The Interest theory of rights can thus be seen to depend upon the same formal conditions as the Will theory. ${ }^{30}$

This period in the history of the common law is nevertheless of some importance for an understanding of the development of the idea of a right within legal thought. For the emphasis on remedies reveals the common law as a form of moral association underpinned by an idea of the moral life of the polity as an unstable and deeply irregular landscape in which no level horizons for moral reflection are possible. ${ }^{31}$ The virtue of the common law was its adaptability: each case to come before the courts was different, because no two cases arose in exactly the same way, or in exactly the same circumstances, and thus each case demanded precise and careful deliberation rather than a tailor-made judgment fashioned from stock rules and principles. The strict rules of the system of writs were thus designed to set each case within specific limits, to render their peculiar features intelligible to judges who could then bring their amassed experience to bear on those facts. Legal decisions created precedents only informally: not by laying down formal rules to be followed in the future, but instead by sharpening judicial awareness of dimensions to a problem: 'A clearly focused precedent would articulate the custom [of judges] better than the oral culture of judges, but it was not binding.' 32

The rationality of the common law thus consisted in the thought that the distinctive features of each case demanded close and separate attention, and could be brought within the scope of broad and categorical principles only at the risk of distortion. Yet the legal order was ultimately to undergo a shift away from a concern with procedures and remedies, and towards the notion of a system of established rules. This shift is reflected in the legal writings of the time: Thomas Starkie, in his Inner Temple lectures of 1834, argued that 'The first and great business of the law is, to define rights and correlative duties of all kinds, whether they be public or private . . . [I]n our law, the extent of the right is limited and defined by the extent of the wrong.' ${ }^{33}$ Legal rights thus gradually came to be identified not with broad and variable arguments concerning the justice of a state of affairs, but with an established body of rules which 'limited and defined' the bounds of permissible and impermissible action.

The continuing association of rights with remedies is of great importance in this context. The traditional common law had viewed rights as a claim for

30 That is, conditions which make the idea of a subjective right intelligible. Common law actions for remedies thus could not be analysed as the application of legal protections for Hohfeldian claim-rights established in advance of their being violated.

31 I borrow this image from Nigel Simmonds (above n.11).

32 Lobban, above n.26, 79. See also D. Lieberman, The Province of Legislation Determined: Legal Theory in Eighteenth Century Britain (Cambridge, Cambridge University Press 1989). As a number of common law historians and scholars have pointed out, a formal and developed notion of stare decisis depends upon an effective system of law reporting wherein the reasoning of judges is recorded and preserved.

33 Law Examiner \& Law Chronicle iii, 172-73, quoted in Lobban, above n.26, 187. 
the redress of a wrong which lay effectively in private hands. The law provided mechanisms for redress, through the establishment of complex forms of action, and it was up to each litigant to pursue a claim by selecting the relevant form. The shift from a remedies-based conception of law to a rule-based one represents a clear shift from a customary to a statist view of law: the realisation had begun to dawn on eighteenth and early-nineteenth century lawyers that the law had become more than a system for redressing wrongs, but could be seen in more general terms as an instrument of social engineering and rule-based governance. ${ }^{34}$ The law thus came to be represented as a system of imposed rules and sanctions constituting public and general standards of conduct, and a distinct system of doctrinal ideas and principles through which individuals could organise and structure their private lives. Rights featured importantly within this bifurcated notion of law as private instruments through which individuals could exercise control over aspects of their lives, by making decisions in relation to the doctrinal rules as they affected their interpersonal relationships: by waiving or asserting claims, exercising powers and waiving immunities, and by ordering their affairs within areas of liberty between the rules and obligations. The common law thus operated in a context in which rights were not identified with, but opposed to, collective measures for the protection of individual interests.

\section{Rights, Powers and the Will}

The modern lawyer confronts a legal order of increasing size and complexity. Within this complex world, the categorical divisions adopted or presupposed by the practitioners of the nineteenth century seem inevitably contrived and increasingly out of step with reality: for we are used to moving within a legal world in which complicated statutory regimes fuse with developed systems of doctrine to regulate private and commercial contracts, compensation for personal accidents, the use of property and the like, and we accept such amalgamated approaches as an unproblematic aspect of legal life. The idea of the law as embodying two distinctive but interconnecting realms, one system of imposed rules establishing public standards of conduct, and a separate system of evolved doctrinal rules for the regulation of private life, comes across as artificial when measured against today's complex realities; whereas the view of law as a single, coherent and integrated system of principles addressed at once to the large concerns of state and the small detail of private lives, strikes the mind as a plausible and powerful insight.

Fuller was one of many jurisprudential writers who were aware of this general shift in legal thinking, and who sought either to understand it or to contain it. ${ }^{35}$ Fuller had attempted to separate those cases in which a litigant has some meaningful control over the way in which her interests and claims

34 See Lobban, above n.26, 204, and S.F.C. Milsom, 'The Nature of Blackstone's Achievement' 1 OJLS (1981) 1 .

35 See for example M Cohen, 'The Basis of Contract' 46 Harvard L Rev (1933) 553; R. Pound, 'The End of Law as Developed in Legal Rules and Doctrines' 27 Harvard L Rev (1914) 795; more recently Milsom, above n.34, and D. Kennedy, 'From the Will Theory to the Principle of Private Autonomy: Lon Fuller's "Consideration and Form"” 100 Columbia L Rev (2000) 94. 
are represented, from those in which polycentric features of the case make the litigant's participation in legal argument meaningless. Yet Fuller was also aware that ' $[\mathrm{t}]$ here are polycentric elements in almost all problems submitted to adjudication ...' and that the distinction between polycentric questions and 'straightforward' doctrinal problems 'is often a matter of degree'. ${ }^{36}$ Since adjudication operates in a context wherein doctrinal rules are increasingly underpinned and supplemented by black-letter provisions (and where those black-letter provisions are fleshed out and interpreted against the background of established doctrinal ideas or general conceptions of 'right' ${ }^{37}$ ), it becomes difficult to point to cases in which a ruling as to the rights and duties of the parties will have no wider, unforeseen impacts upon the treatment of future cases. Indeed, as Fuller noted, any system of laws containing a reasonably robust doctrine of precedent will render the separation of public and private spheres in this way largely artificial. ${ }^{38}$ Fuller nevertheless believed that the point of such a separation was intelligible: 'It is a question,' he said, 'of knowing when the polycentric elements have become so significant and predominant that the proper limits of adjudication have been reached.' 39

I have suggested that the distinction between the Will theory and the Interest theory should be understood as proposing differing conceptions of the boundary of private law. Whereas the Will theory sits comfortably within a theory of legal reasoning which minimises the polycentric dimensions of adjudication, the Interest theory propels polycentric problems into the very heart of legal reasoning by defining the right in terms of the good. Such a move, I argued, is incompatible with the liberal presuppositions of much of our legal and political practice. The modern political world is one in which morality is viewed in a context of plural conceptions of the good rather than of monolithic values. Having given up the idea of a pre-civilised state of nature structured by natural patterns of right and duty, we confront a social world characterised by perpetual and irresolvable tensions. Little can be inferred about such a world from man's 'natural' state beyond a few general truths about the desirability of peaceful society; but there is nothing about those general truths which could serve as the basis for detailed suggestions about the form that society should take. Since it is in relation to the basic goods that add meaning and structure to our lives that endemic disagreement arises, any attempt to define rights to such goods in terms of the interests we have toward them will inevitably fail to resolve widespread tensions by an appeal to rights themselves: 'rights' will have become, in effect, a mere adjunct to a broader theory of the good which exists in abstraction from the beliefs and desires of ordinary people.

Liberalism stands in some tension to forms of reflection which seek the resolution of conflicting moral standpoints in sweeping theories of the good.

36 Fuller, above n.12, 397.

37 I refer, of course, to the Human Rights Act 1998.

38 See also Cohen, above n.35. Any system of private rights depends, of course, on collective recognition and enforcement. It is therefore difficult to imagine a form of legal order in which there would be no public interest in the content of private law rules. The issue for the Will and Interest theories, however, concerns the peculiar form in which such interest is (or should be) manifested.

39 Fuller, above n.12, 398 . 
For we can view perpetual disagreements concerning the good not as problems to be ironed out by some more encompassing moral theory, but as features which define the human condition. Human societies can then be looked upon as evolved responses to the problem of disagreement, and as thus constituting a source of moral insight into human nature. The Will theory of rights offers a particularly attractive way of looking at the liberal political order. If there are no natural or predetermined social roles and hierarchies, but simply a set of problems up for collective determination, then no aspect of individual lives is in principle off limits to public scrutiny and regulation. It follows that a meaningful doctrine of individual rights must be capable of shielding individuals from the intrusive gaze of the state (as well as intrusions by other people) by establishing and preserving blocks of private life over which those individuals exercise a measure of normative control. Without the presence of legal claims against interference, liberties, immunities and so forth, the notion of individuals having interests distinct from those of the collectivity would have become a comforting fiction.

The notion of a 'right' is thus connected in liberal thought to the idea that individuals possess certain abilities and characteristics which do not belong to society, and over which society cannot make unlimited claims. The powerful intuitions which drive both the Interest theory and the Will theory therefore reflect an association between rights and interests which is indirect rather than central. But whereas the Interest theory downplays this possessive quality of rights by viewing interests as the product of collective determinations, the Will theory more clearly articulates the justificationary basis of rights: so long as individuals retain a sphere of personal autonomy in which they can resist injunctions to act to their detriment in favour of the common good, they remain free to formulate and pursue courses of action whether or not such actions conform to broadly conceived collective interests. It is this sort of freedom which underpins the liberal ideal of the individual as a thinking being with a level of self-control, rather than a mere drone existing for the benefit of the hive. Rights are thus not something which each person has insofar as society grants them out of its aggregative and distributive projects, but something which a person owns. ${ }^{40}$ The recognition of such rights is, of course, underpinned by mechanisms of collective enforcement, so that the boundary between the public and private realms cannot be drawn with any rigidity. The integrity of rights is hence best preserved by the development of a body of clearly defined doctrines and rules which can be contemplated and applied in relative isolation from more general investigations into the political good.

It was Hart who first clearly traced the different ways in which a person's entitlements can serve the right-holder's autonomy. ${ }^{41}$ Drawing on Hohfeld's analytical distinctions, Hart observed that the unifying feature of the four Hohfeldian entitlements, the reason we are tempted to refer to such distinct

40 See C.B. Macpherson, The Political Theory of Possessive Individualism: Hobbes to Locke (Oxford, Clarendon Press 1962).

41 H.L.A. Hart, 'Definition and Theory in Jurisprudence' in Essays in Jurisprudence and Philosophy (Oxford, Clarendon Press 1983) 21-48, 35-36. See also Hart, 'Legal Rights' in Essays on Bentham (Oxford, Clarendon Press 1982) 162-93. Hart's suggestions have been taken up and further explored and refined by later writers. See e.g. Simmonds, above n.11, 218-29. 
ideas as 'rights', is that ' . . in all four cases, the law specifically recognises the choice of an individual either negatively by not impeding or obstructing it (liberty and immunity) or affirmatively by giving legal effect to it (claim and power). ${ }^{42}$ Hart's insight serves as an important reminder of the connection between rights and remedies: by focusing on a person's ability to make normative determinations about his situation, or to pursue his projects unimpeded by the choices of others where he lacks the ability to make positive determinations, the Will theory successfully depicts the way in which rights operate within the established and stable boundaries of relatively precise doctrinal rules. The focus of adjudication tends to be upon the historical circumstances of each case, addressing broad and polycentric questions of right and social good comparatively rarely. The common law approach to justice thus reflects a concern with the way in which relations between the parties came about. It is therefore within the context of fairly focused doctrinal and circumstantial concerns, rather than in a spirit of wideranging political and social inquiry, that questions of legal right are typically addressed.

But why, a defender of the Interest theory might respond, should we construe those more focused concerns as concerns with the right-holder's choice, as opposed to his wider interests (say, in having his decisions taken seriously or in being a proper focus of respect in a context where other interests and values are at stake)? In dwelling on the idea of choice, do we not simply presuppose the validity of the Will theory over the Interest theory? After all, we can point to the presence of legal rights - such as employment rights which, though unwaivable by the right-holder, nevertheless seem to protect important aspects of the right-holder's wellbeing, and are thus ordinarily and plausibly thought of as constituting 'rights'. Statutory rights against unfair dismissal, or racial prejudice in the workplace, or the entitlement to a minimum wage, undeniably enhance the lives and wellbeing of individuals in various important respects, whilst at the same time reducing the scope of those individuals' options and choices over their normative situation. Indeed, it is precisely the inability of the right-holder to bargain away such rights that constitutes their importance as modes of protection. Moreover (it is said), it is not at all clear that the possession of a right invariably depends upon the right-holder's competence to make effective normative choices. The Will theory, it is said, excludes the possibility that children, mentally incapacitated or dead people can hold rights; and yet it is just in the case of inarticulate or vulnerable persons that rights seem to be most important and uniquely apt as a means of protection.

If we are to treat this accusation as more than a humdrum reminder of the fact that our ordinary intuitions about rights can be regimented, conceptually, in different ways, then we must trace the Interest theorist's objection to an evaluative standpoint which attaches significance to the possession of a right even where such possession advances some aspect of the right-holder's wellbeing at the cost of personal autonomy. In that respect, objecting to the Interest theory on the ground that it makes it difficult to preserve the relationship of the common law system of adjudication to its own past, may seem a somewhat blunted response: the common law can be presented as a

42 Hart, 'Definition and Theory in Jurisprudence', above n.41, 35. 
fully coherent and linear tradition of thought only by resorting to distortive analytical abstractions. Should the implications of the Interest theory lead to the abandonment of deeply ingrained understandings and intuitions about the common law system, the need to preserve traditional understandings of rightbased reasoning must therefore find expression in values other than that of tradition itself. I have suggested that a conception of rights which emphasises individual interests at the expense of autonomy should be rejected due to its association with fairly objectionable, if currently fashionable, forms of political idealism. Yet the Interest theorist may wonder whether idealism is all that objectionable when compared with the political assumptions of the Will theory. For might we not conclude, on reflection, that it is more important to establish solid protections for aspects of individual wellbeing than to place ultimate control over those protections in the hands of individuals who make their choices in the grip of market forces?

I think there are at least two powerful responses to these objections. These can be stated succinctly, but require considerable elaboration in order to serve as defences of the Will theory:

1. It is central to the liberal idea of politics that judgments about a person's interests are, as far as possible, judgments of the person whose wellbeing is at stake. In a large community where the simultaneous and uncoordinated pursuit of projects demands extensive regulation, this 'possibility' generally takes the form of individual power over the enforcement or waiver of duties established in accordance with legal rules, rather than the ability to determine the content of those rules in any direct way. Situations where both the content of the rules and the enforcement/waiver of duties created in accordance with the rules lies in the hands of empowered officials could be represented as instances of the possession of a right only by casting doubt upon liberal explanations of the basis of the rule of law.

2. In all situations where we tend to speak of 'rights', the holder of the right manifests de facto control over the exercise of the right even where officials retain juridical power over the enforcement of duties. The concerted attempt to remove such vestigial control from individuals would require the development of invasive bureaucratic and administrative forms of regulation which, even if practicable, would thoroughly undermine the community's status as a liberal polity. The character of 'unwaivable' rights is thus considerably misrepresented by the Interest theory.

These issues are best explored in the light of a discussion of legal powers. Recent defences of the Interest theory have correctly centred upon the notion of legal powers as identifying the main area of contention between the Will and Interest theories. For, in the absence of Hohfeldian powers to waive or enforce duties correlative to rights, the right-holder would seem to lack the requisite control over the exercise of the right demanded by advocates of the Will theory. We might thus conclude that a legal entitlement qualifies as a right under the Will theory only where one of the basic Hohfeldian advantages is exercised in conjunction with a validly conferred Hohfeldian power. There is a substantial core of truth in these propositions which reflects importantly on the nature of legal rights. Yet care must be taken not to distort that truth in the form of broad assumptions about the matters at issue between rival theories. As Hart observed, rights can defend the right- 
holder's choices positively or negatively. Positive recognition is given to a person's autonomy in the form of claim-rights and powers, through which the right-holder is legally enabled to make autonomous choices which directly affect the scope of his entitlements relative to the entitlements of others. Negative recognition is accorded to choice through legal liberties and immunities: liberties define a sphere of freedom from obligation in which the right-holder can make decisions in relation to possible courses of action; whereas immunities defend the right-holder from non-consensual changes (as well as some consensual changes) to her existing entitlements. The negative/positive dichotomy, though illuminating in many respects, has nevertheless served as an obstacle to the understanding of the complex relationship between these various forms of Hohfeldian entitlement and the possession of legal powers.

In a recent and extremely powerful essay, Matthew Kramer defends a version of the Interest theory on the basis of an analysis of legal powers. To hold a legal power, Kramer contends, a person 'must be legally and factually competent to exercise it; moreover his holding of the power must derive directly or indirectly from some legal norms or decisions.' 43 If we regard the main issue between the Will and Interest theories as the presence or absence of such powers in conjunction with various forms of legal advantage, then it may seem as if the Will theory is presented with a rather elementary problem: for we can readily bring to mind examples in which the presence of important rights depends upon precisely the sort of trade-off between autonomy and wellbeing which the Will theory refuses to countenance. ${ }^{44}$ For the efficacy of minimum wage schemes, anti-discrimination measures and the like, as well as the possibility of ascribing rights to children and the insane, depends upon dissociating basic forms of legal advantage from powers relating to their enforcement. Broad political visions aside, the threshold for the adequacy of a theory of rights must include the ability to absorb such insights as part of our collective understanding of what rights are.

The problem of ascribing rights to legally (or factually) incompetent rightholders can be met reasonably quickly, so I propose to deal with that first. Kramer gives the following account of the 'prime point of controversy' between the Will and Interest theories:

"According to the Interest Theory, anybody $X$ can hold a legal right irrespective of whether he holds any legal power to enforce/waive the duty that is correlative to the right. According to the Will theory, by contrast, $X$ holds a legal right

43 M.H. Kramer, 'On the Nature of Legal Rights' 59 CLJ (2000) 473-508, at 474. (Hereinafter, Nature.) See also Kramer, 'Rights Without Trimmings' in Kramer, Simmonds \& Steiner (above n.3).

44 I am aware that the following pages might give a misleading impression of the enormous analytical strengths of Kramer's essay. Much of the following argument is inspired or provoked by that essay, and it is indeed the potency and range of Kramer's arguments against the Will theory which demand a fairly substantial engagement with the detail of Kramer's arguments. 
if and only if he holds the legal power of enforcing/waiving the correlative duty." 45

Such a formal characterisation of the Will theory might seem somewhat surprising to someone in possession of Hart's distinction between positive and negative protection; for that distinction rested not on any formal characteristics rights may be presumed to possess, but on a substantive vision of the purpose which rights might be thought to serve. Immunities and liberties, for example, do not inevitably depend upon the right-holder's possession of legal powers of waiver in order to discharge their function of protecting aspects of the right-holder's autonomy. All the same, we might interpret 'right' in this context as specifically designating Hohfeldian claimrights, in which case the presence of legal powers of waiver may well be a substantive condition for the conferral of rights. ${ }^{46}$ Kramer's argument then proceeds to outline the attractions of the Interest theory over the Will theory in this context:

"Because infants and mentally incapacitated people and animals and dead people are not competent to demand or waive the enforcement of their entitlements, their holding of genuine legal rights cannot involve their holding of the legal powers to demand/waive the effectuation of those rights. There is no alternative to placing such powers in the hands of others (parents, guardians, public officials and so forth), if infants and mentally incapacitated people and animals and dead people are to have any rights at all. Hence, given that there is no alternative, and given that the conferral of genuine legal rights on the aforementioned people and creatures is highly desirable, the fact that other people exert the powers to enforce/waive those rights is not a cause for keen consternation." 47

A short response is this: if such right-holders lack the ability to exercise legal powers, then they ipso facto lack the ability to wield and assert legal claims, in the form of Hohfeldian claim-rights. Now, such an implication is not immediately disturbing to the Interest theorist since he will not regard the ability to wield legal claims as a precondition for the possession of such claims. Claim-rights are accordingly treated by Interest theorists as mere markers of protected domains, whether of choice or of interest. A legal power must thus be called into play to make legal determinations about how a domain of legal protection is to be defended or altered. A major reason for the discomfort we feel over the ascription of rights to incompetents derives from assumptions about the nature of interests: though claim-rights are (for the Interest theorist) markers of interests, the notion of 'interest' is defined in a way which might not coincide, or may coincide only contingently, with the

45 Kramer, Nature 474.

46 In fact, Kramer regards the presence of legal powers as a conceptual, rather than a substantive condition, for the conferral of rights. My reasons for disagreeing with this suggestion will become evident in what follows.

47 ibid., 478. See also N. MacCormick, 'Children's Rights: A Test-Case for Theories of Right' in Legal Right and Social Democracy (Oxford, Clarendon Press 1982) 154. 
professed interests of the putative right-holder. ${ }^{48}$ The possession of a claimright would not by itself allow the right-holder (incompetent or otherwise) to make any significant legal decisions about how his interests are to be protected, traded or modified (or abandoned) in a given context. The most that such a right-holder could do is call the claim-right into service in a very limited way (by acting in ways consistent with assumptions that the right will be respected, or by informally resisting intrusions by calling attention to the existence of a specific duty). But the lack of a legal power on the part of the alleged right-holder to make any significant changes to his legal position relative to others, by enforcing or waiving the right against specific persons, is the key reason why we ordinarily feel uncomfortable about ascribing rights in such contexts.

For a claim-right to be operative - that is, to have actual legal effects - it must therefore be associated with a legal power, regardless of who holds that power. A claim-right-plus-power is therefore minimally sufficient for the existence of a genuinely operative legal entitlement against unwanted intrusion (or for assistance). Given that claim-rights can be wielded only through the use of such powers, the situation of the incompetent right-holder is thus misleadingly characterised by the Interest theorist as presenting a rigid contrast with the Will theory. For the question is not one of rigid analytical boundaries (between entitlement and non-entitlement), but of whether the presence of choice in relation to the way in which the right is exercised is sufficiently analogous to the situation of a competent rightholder being in full control of that choice to make an attribution of right plausible in the case of the legally incompetent. A competent right-holder, $X$, rarely wields and asserts a claim-right himself; that business is usually carried out by a lawyer acting as $X$ 's agent in accordance with $X^{\prime}$ 's instructions and consent. A situation in which an incompetent right-holder, $Y$, is consulted about changes to his legal position brought about by the use of a legal power held by $Z$ (a parent or guardian, say), and which is used by $Z$ in a manner consistent with $Y$ 's expressed wishes, is thus sufficiently analogous to the position of the competent person as to warrant an attribution of right to $Y$, albeit that the right is in fact exercised by $Z$. We might, of course, question on more general grounds whether claim-rights can be exercised on behalf of another and yet still be referred to as that person's claims; but since the Interest theory's ascription of rights to the incapable depends upon so doing, the Interest theorist ought to hope that we can. ${ }^{49}$

In contrast to cases which closely resemble $X$ 's position on the matter of choice, we can imagine instances in which $Z$ exercises $Y$ 's claim-rights with no regard for $Y$ 's own stated preferences (and perhaps also without regard for $Y$ 's interests at all). In such cases, it is clear that the analogy with the

48 Indeed, depending on further assumptions about collectively determined interests, the interests protected by the right may even differ from the right-holder's actual interests (irrespective of the latter's own views).

49 At least in the case of the very young, it is not clear that we can. As Hart pointed out, moral conditions placed upon our actions towards children do not seem to be based upon respect for rational autonomy, but on a generalised concern for aspects of their welfare. This is not a reason for the assertion that children do not possess rights, but an explanation of a proposition which (if it holds at all) holds independently of the Will theory. 
possession of a right by $X$ has become broken-backed: even if $Z$ overrides $Y$ 's known preferences with good reason or good intention, or if $Y$ is incapable of expressing preferences at all, the lack of control by $Y$ over his legal situation is so pronounced as to undermine the rationale for characterising $Y$ 's position as one involving right rather than regulation on the basis of a concern for welfare. In relation to the legally incompetent, therefore, we are presented not with a rigid categorical division between cases of right-holding and cases of non-right, but rather a continuum of possibilities which are more or less like the standard case of the competent right-holder. The Will theory is thus able to explain our commonsense judgments in such situations (and the level of discomfort we feel about the attribution or denial of right) in a more nuanced way than can the Interest theorist.

A quite different, and more complex, problem is presented by rights which seem to trade autonomy for wellbeing in line with broad social policies. A society will engage in such trade-offs where there is a strong reason to believe that individual or collective welfare would be threatened if certain choices were left to the uncoordinated wills of individuals. The withholding of benefits or the application of penalties on grounds of race is one of a number of issues recognised as being too important to both individual wellbeing and to the community's collective self-image to be left to private decision. Where a person chooses to sacrifice such interests in order to gain some other benefit, or to avoid some threatened consequence, he not only acts against his own welfare, but also erodes and undermines his community's values. There is nevertheless a good deal of sense in the notion that such protections should be counted among a person's rights. Minimum wage laws, for example, undoubtedly confer complex entitlements on workers (including claim-rights to be remunerated above a certain level), but simultaneously restrict the aggregate of choices open to a person to act within the law: ${ }^{50}$ certain otherwise valid contracts of employment can no longer count as legally enforceable bargains.

Whilst it seems intuitively correct to speak of rules of this kind as conferring rights, such regulatory regimes vary the extent of individual entitlements in many ways, both positive and negative. By altering our perspective, we can examine those effects in different ways: a focus on each person's claimrights to levels of remuneration from within a given range are naturally presented as affording positive recognition to choices which each person might make to accept offers and make legal bargains within that range. Viewed from the perspective of the consequent reduction in the number of opportunities for meaningful employment, however, we are hardly likely to regard the lack of legal recognition accorded to a person's choice to accept an employment offer in violation of such protective and regulatory norms as a 'right'. We will rather look upon those norms as having conferred extensive disabilities and liabilities along with liberties and claim-rights. The issue of interests is tangential to such questions: our willingness to ascribe rights to people in the light of wide-reaching normative regimes is

50 In restricting the scope of legal action, such laws effectively reduce a person's freedom overall: see M. Kramer, The Quality of Freedom (Oxford, Oxford University Press 2003). 
quite separate from the judgments we make about the way in which those regimes distribute interests and costs. ${ }^{51}$

Where rights are conceived as protected choices, it is possible to preserve the intuition that regulatory regimes should be presented as a balancing of rights against wider concerns with welfare, rather than a straightforward balancing of rights against other rights. A concern with individual wellbeing does not invariably take the form of a concern with the recognition of rights. The project of effecting some overall shift in the distribution of benefits across society (such as the institution of a basic level of remuneration) is not the same project as balancing the rights of every person to secure and pursue a worthwhile life: it constitutes instead the desire to modify the extent of each person's legal entitlements in order to secure some other social advantage (aside from the protection of rights), such as the workability of a system of protections which would collapse if left to the play of market forces. The Interest theory erodes the integrity of rights by failing to recognise such developments as concerning the boundary between individual rights and collective welfare rather than dealing exclusively with the boundaries between competing rights.

Rights conferred by statute as part of some wider strategy or social goal are rarely considerable in isolation from the complex regulatory mechanisms which guarantee the effectiveness of those rights as demanded by the strategy. It is perhaps the tendency of the Interest theory to look upon such regimes holistically which explains the theory's treatment of regulatory provisions as aspects of questions of right. Regulatory provisions are then capable of being seen as directly defining the boundary between competing rights, rather than as higher-level norms defining the operative bounds within which rights compete. The Will theory, it seems to me, offers a credible and attractive explanation of why the benefits conferred by legislation should be looked upon as giving rise to rights, whilst preserving the distinction between rights and regulation. We have already seen how the trade-offs between autonomy and wellbeing which are typical of statutory regimes of regulation can be presented as refutations of the choice-orientated view of rights only by assuming that the questions raised by regulatory measures must be dealt with on the same level as questions of individual right. It is the failure to see that there are in fact two distinct sets of questions involved (questions about how individuals' lives are to be regulated in their own and the general interest, and questions about the effects such regulations will have on the complex web of entitlements which obtain between those individuals) which leads the Interest theorist to suppose that questions of choice are to be disposed of within the language of rights (by drawing a distinction between waivable and unwaivable rights) rather than a context in which rights compete with other values and interests. Yet the interplay of interest and choice is perhaps more complicated than we might think.

Let us consider the example of statutory employment rights which protect workers from unfair dismissal on grounds of race, religion, disability etc. If

51 That is, we can regard a regime $R$ as distributing costs and interests in a way which is broadly beneficial (perhaps deeply beneficial) to individuals in society, but as bringing about those benefits at the expense of certain rights. For a sharply different view see Kramer, above n.43, 94-96. 
such rights are to operate successfully, it is clear that employees must possess legal disabilities preventing them from alienating their legal protections as part of the normal bargaining process between employer and employee. We can therefore view such protections as helping to define the kind of agreement which can exist between the parties to a contract of employment: such agreements will include duties owed by the employer towards the employee which the latter cannot give up or trade for some other proposed benefit. As many defenders of the Will theory have pointed out, however, the inalienability of the rights to which such duties are attached is connected with the issue of waiver only through quite complex chains of reasoning: for although the right-holder lacks the legal power to bring such duties to an end, he can clearly control the application of the duty by deciding whether to sue or not to sue. ${ }^{52}$

The choice of the right-holder thus remains central in determining when the right will be brought into play in the service of his interests. ${ }^{53}$ The inalienability of rights addresses a separate question from that of identifying the right-holder's interests: the permanency of such rights secures anterior goals, such as the workability of a system of protections, which define a context within which an individual can make choices about his own normative situation. By equalising the bargaining powers of the parties, a system of inalienable rights (though clearly reducing the number of choices open to each person) creates conditions in which an individual's remaining choices carry meaningful weight. Rights of this kind are therefore not vastly different in kind from ordinary contractual rights, but only in degree: statutory regimes ensure the establishment of rights which, except for inequality of bargaining power, might have come about through contractual negotiation in the usual way. Such rights will tend not to affect the scope of a right-holder's choices significantly (unless the right-holder adopts strange preferences such as the preference to be discriminated against on racial grounds), but will merely render certain operations with the right, such as bartering, unenforceable. Yet even in the case of ordinary contractual rights, rules such as those requiring valid or additional consideration operate to

52 See e.g. Lucy, above n.4, 195. The right-holder may, of course, possess some residual powers to bring the duties to an end: for example by serving notice on the contract as a whole, or perhaps by electing not to raise an action upon the duty within the scope of prescribed time-limits. We might think of the alienating/notexercising distinction as pointing to different ways in which a right can be waived.

53 There will be occasions, however, on which this is not the case. Under Art.44 ACHR, for example, any person can institute proceedings against a perpetrator of torture, irrespective of the victim's consent. Examples of this kind will be comparatively rare, but in any case raise a separate issue which does not threaten the Will theory: here, a certain person $X$ has a claim-right, but the legal power associated with the right is vested generally in a group of persons (including $X$ ). Accordingly, $X$ possesses no immunity from non-consensual changes to his legal position due to the exercise of that power by others. The position is thus characterised not by $X$ 's possession of a claim-right-and-disability, but by his possession of a claim-right-and-power-and-liability. Will theorists (and many Interest theorists) will be uncomfortable with the presence of such a liability, but that discomfort does not undermine the validity of the Will theory's analysis of that situation as one in which $X$ has substantial though not total control over a claim-right. 
place restrictions upon the circumstances in which rights can be alienated, waived or enforced. The inability to bargain away the right at the outset - as opposed to waiving performance of the duty when breached - will represent no significant loss of autonomy to the vast majority of right-holders, and it is thus appropriate to refer to such schemes in a general way as being concerned with the creation of rights.

While such explanations have a good deal of force, we might nevertheless harbour some suspicions that the notion of 'waiver' cannot be so easily restricted to a decision over whether to sue: the distinction between alienability and enforcement might prove important in some respects, but (we might feel) it is hardly absolute. Where officials of the state retain the power to waive or compel performance of duties on their own initiative, or where statutory duties can be modified or eliminated only through further acts of amending legislation, the gap between alienability and enforcement becomes somewhat tenuous and unreal. Such apparent problems for the Will theory evaporate, however, if we view the boundary between right and nonright as a matter of evaluative judgment rather than analytical stipulation. Rights can be associated with powers of waiver in numerous possible ways, each with its distinctive effects upon the right-holder's choices. In some of these cases, the right-holder's vestigial control over some legal advantage will incline us to regard that advantage as a 'right'; in other cases we might view the holder as having insufficient power to decide the application of advantageous legal rules to his own situation, and thus regard his position as regulated rather than entitled. There is no reason to suppose that such judgments are governed by strict semantic criteria, or by values which apply evenly to every case.

Where Interest theorists speak of 'unwaivable' rights, they presumably have in mind situations where the right-holder enjoys the benefit of some advantage (a claim-right or immunity, say) unadorned by any power to determine the way in which that advantage applies to her situation. In such cases, we would then look upon the person concerned as having a right, coupled with a disability to deflect the benefit of the right. Might we not then view anti-discrimination rights, such as those which function in the employment context, as Hohfeldian immunities associated with disabilities against the deflection of benefit?

I think not. There are certainly conceivable situations in which the subject of some legal advantage retains no vestigial power whatsoever to deflect the unwanted benefits of that advantage: we might, for example, consider the position of a free-thinking member of a caste-system, who may have extensive claim-rights against all physical contact by members judged to be 'inferior' within the social hierarchy, but who objects to the system of rules and regulations which perpetuate such class distinctions. True, such a person could ignore or even encourage infractions of his own claim-rights, but he would be incapable of waiving the duties of the underclass towards him, whom the state may continue to punish mercilessly. Could we really speak of measures which establish categories of unlawful interference in this way as conferring rights ${ }^{54}$ (Suppose the man wished to marry a woman from

54 We are particularly likely to answer in the negative if the person encouraged the infractions as part of his efforts to instigate a change in the regime - by 
within the underclass, but was prevented from doing so by the presence of such 'rights'?) In the vast majority of non-oppressive situations, the subjects of legal advantages do not possess such extensive disabilities, but continue to exercise vestigial control over the application of their entitlements as they see fit. The right-holder, in most cases, can decisively shape the legal response to her situation by electing to raise an action, or in some cases merely by reporting infractions. Only in cases where the recipient of some advantage has no possibility of shaping the outcome (where, for example, the failure to receive some benefit, or to report the infraction of a duty, is itself an actionable wrong) is that recipient wholly devoid of legal powers to determine the application of entitlements to her life.

The vast majority of regulatory systems will therefore invest the right-holder with interstitial powers to enforce or waive correlative duties. It was HLA Hart who first drew attention to the propensity for claim-rights, powers and immunities to establish a perimeter of indirect protection for legal liberties whose exercise might otherwise be rendered worthless: since liberties consist merely in the absence of duties to refrain from performing the permitted action, liberty-holders are quite unprotected from interference by others, in pursuit of their own liberties, which can frustrate and render nugatory such attempted exercises of liberty. The liberty to carry on a business in a hostile marketplace, for example, enjoys considerable protection from established claim-rights against libel, theft, restrictive practices, insider dealing and the like. No corresponding attention has however been paid to the way in which a person's established rights can protect and define interstices of power. For each person typically possesses an array of immunities against prosecution for failing to raise or pursue actions established as possibilities by statute, coupled with general immunities against alteration of one's existing legal entitlements by the action of officials seeking to raise or abandon legal actions on one's behalf. The law also confers myriad bilateral liberties which make possible appropriate choices about how each person will manipulate their other entitlements in the world of social interaction, by asserting and pressing claims, threatening legal action, or securing alternative benefits by agreeing to waive an action at a particular point in time. ${ }^{55}$ The

encouraging inter-class contact, say, and in initiating such contact as a means of garnering signatures on a petition or for the purposes of organising a pressure group.

55 It will be clear from my analysis of vestigial powers that I disagree with Nigel Simmonds's fascinating suggestion that Hohfeldian claim-rights form a specialised kind of power within Hohfeld's analytical scheme, distinct from the generalised notion of power which we know by that more familiar name. This specialised form of power is exactly a power over the enforcement or waiver of duties. (See Simmonds, above n.11, 224). It is conceivable that a system of legal regulation might confer claim-rights (say) on individuals unadorned by any Hohfeldian powers of waiver at all (whether possessed by that individual or by anyone else). In such cases, duties would have been established to which no legal remedy corresponds. Thus, to the extent that it is conceivable that duties might exist to which no enforceable penalty is attached, naked claim-rights of this kind emerge as possibilities. But then in what sense would these amount to genuine juridical relationships, as opposed to aspirational expressions of policy or best practice? It is perhaps similar thoughts which lead Hart to remark that 'If there are legal rights which cannot be waived, these would need special treatment.' (Hart, 
state's regulatory mandates will thus almost inevitably confer significant and important interstices of power.

The question of the exercise of powers in relation to individual entitlements is a complex and important one. The Will theory reflects that importance and that complexity very well; for it is surely in connection with the exercise of control over aspects of one's normative standing that the notion of a right is most naturally and appropriately used. The foregoing analysis suggests just how subtle and variegated such control can be. The Will theory of rights does not dogmatically presuppose the existence of a 'right' whenever immunities, claim-rights or liberties are brought within the scope of a legal power; for the notion of a right, like the question of control, is an evaluative one which can change within a context of varying degrees and kinds of vestigial power. The notion of a 'right' is not one which derives its shape from the drawing of convenient analytical boundaries, but from judgments whose conceptual associations are inseparable from the point of reflecting on the standing of individuals vis-à-vis their fellow men and the state. If the point of making such judgments reflects a concern with delineating those areas in which a person's life is free of collective control, it becomes clear that not every conferral of a legal advantage will amount to a 'right'. Certain immunities, for example, will qualify as rights even where the holder retains very little vestigial power over their application, since they provide important forms of negative protection to personal autonomy. (We can view immunities against wrongful arrest and prosecution as being of this kind.) Other readily imaginable unwaivable immunities, on the other hand, do not by ordinary standards count among a person's rights. The rules of a respected scholarship programme, for instance, may provide that applications from scholars over the age of 30 will not be considered. If I am above that age, I am legally immune from having my existing entitlements enriched by the exercise of any power of the awarding body in deciding to whom the scholarship should go. The relevant difference between these two immunities lies in the point for which they were conferred: my immunity from arbitrary arrest exists to protect me from intrusive, autonomychallenging powers of state officials, whereas the point of the immunity conferred by the scholarship rule is not to protect me, but to establish parameters within which others can compete on a level playing-field. Whereas the first is focused on my choices, the latter is the consequence of the choices and actions of others. ${ }^{56}$

above n.41, 36. For a quite different and detailed treatment see Kramer, Nature, 481-95.)

56 The same holds true of the other Hohfeldian relations. A power to waive or enforce contractual rights is naturally spoken of as a right since it allows me to make significant determinations about my legal relationship with others. But if I crash my car into another's, I also exercise a legal power since I thereby alter my legal relationship vis-à-vis that person (and anyone who is injured as a result of the crash, and presumably his and my insurance companies). It would be ludicrous to speak here of a right to crash my car, since crashes are generally accidents rather than the outcome of a deliberate choice: the power here exists as a mere consequence of unintended action, not as a legal protection for an authoritatively recognised choice. 


\section{The Empire of Interests}

Modern legal and political thinking is dominated by the idea that rights protect aspects of individual wellbeing. The value of autonomous decision represents just one interest to be weighed and balanced against others on the dominant view. The conception of interests at work in such thinking is thus an idealistic one in which a person's own prioritising of his interests is 'hardly dispositive' in relation to the legal enforcement or relaxation of interest-protecting duties: ${ }^{57}$

"If all or most of the members of a certain class of people lack the mature or informed judgment that is needed for an accurate appraisal of their own fortunes, then the fact that most of them view a particular practice as undesirable is not determinative of the way in which that practice should be construed. To whatever extent is appropriate, the Interest Theorist's conception of well-being or interests is objective rather than accommodatingly subjective. Although someone cleaving to that conception will typically defer to the evaluative judgments that are reached by most people in most contexts, he will depart therefrom if he has good grounds for thinking that those judgments are misguided or myopic." 58

I have argued that such a view of interests entails the rejection of a form of positivism which is essential to any attempt to deal properly with the 'Protestant' political assumptions which characterise the modern age. ${ }^{59}$ Much of the attraction of the Interest theory can be traced to the changing social conditions of the eighteenth century: the rise of capitalism from the ashes of the feudal order, on the one hand, and the enjoyment of considerable periods of relative political stability and moderate government, on the other, created conditions in which individuals no longer viewed the impending loss of control over important areas of life (such as religious observance or political allegiance) as the most pressing social issue. With liberty no longer under sustained threat, political focus shifted from grand political concerns to a concern for certain sectional interests. The focus on particular interests rather than the general political conditions in which those interests are pursued both emphasised liberal disagreement about the good life, and suggested a solution to the problem of disagreement: for we could construe liberal equality as demanding not the freedom of individuals to pursue widely divergent conceptions of the good within a framework of 'neutral' rules, but the participation of each person in the delineation of a shared

57 Kramer, Nature, 497.

58 ibid. See also 508.

59 One might try to bring such a standpoint in relation to interests within the scope of positivism in other ways: for instance, by recognising that a legal system's Rule of Recognition can absorb such idealistic impulses as contingent features of legal practice. This gambit does indeed achieve a resolution of that analytical tension; but it is not clear what such a diluted form of legal positivism contributes to the attempt to understand the distinctive forces of Protestant political theory: positivism, in these circumstances, would have become detached from its historical immersion in robustly liberal values and ideals. (For a broadly similar accusation, see D. Dyzenhaus, 'The Genealogy of Legal Positivism' 24 OJLS (2004) 39-67.) 
conception of the good distinct from the 'myopic' desires of individuals. ${ }^{60}$ Rights then no longer serve to demarcate spheres of individual activity which are free in important respects from social control, but instead establish focal points for collective concern. Yet a society in which all spheres of personal autonomy have been eliminated or have become the subject of social control, is surely correctly viewed as one wholly devoid of rights.

Kramer has offered an argument purporting to refute this objection. ${ }^{61}$ For, he argues, it is entirely possible to characterise the dismal social conditions of such a society without resorting to the proposition that citizens of that society lack rights. Such a society would be characterised in Hohfeldian terms as one in which individual citizens possessed claim-rights but no powers of enforcement or waiver over the corresponding duties: such powers would instead vest in officials of the state to be exercised in relation to those individuals as and when deemed appropriate. This, says Kramer, does not represent a situation in which citizens lack entitlements (for their interests might be served very well by the array of claim-rights they possess), but one in which those citizens lack the ability to make autonomous choices in relation to the extent of their entitlements or aspects of their general situation. ${ }^{62}$ In such circumstances, Kramer argues, the Interest theory is able perfectly well to capture the awfulness of each citizen's plight:

"In these circumstances, [the citizen] would be roughly akin to people who have undergone the complete amputation of their legs (by public officials) but who hold legal rights against interference with their running in cross-country races." ${ }^{63}$

The point, however, is not whether the Interest theory can aptly convey the awfulness of the plight of citizens within such a society, but what the value of ascribing rights to citizens in this situation would be. That rights can be so ascribed on the basis of the Interest theory's definition of rights is not in doubt; what is in doubt is exactly what is gained by clinging to that definition in the outlined circumstances. The situation outlined is one in which the lack of choice possessed by each citizen to alter (or preserve) some aspect of her legal situation is the most pressing feature stifling her life. That lack of choice is thus properly focused upon by the Will theory as defining the difference between a person's possessing entitlements and a person figuring

60 Nigel Simmonds presents the Interest theory as a (positivistic) response to the failures of Kantian approaches to justice. Despite the reality of these developments, it is doubtful whether the collapse of Kantianism had anything but a very small influence on the development of legal doctrinal thought in the eighteenth century, when compared with the rise of commerce as the principal form of economic activity, and the general tendency towards reform of the system of writs, charted above. These developments were quite independent of the positivism which was emerging as a distinctive force in legal reasoning. See Simmonds, above $\mathrm{n} .11$ passim.

61 In fact Kramer's argument relates only to a society in which all claim-rights are controlled by officials of the state. It is unclear whether the same argument would apply to a society in which immunities, liberties and powers had also become absorbed into state control. I will therefore similarly restrict my remarks to claimrights in the following paragraphs.

62 Kramer, Nature, 480.

63 ibid. 
in a community's political thought as a mere pawn in the state's aggregative and distributive projects. To insist that a conception of entitlement is compatible with both situations is to rob the notion of entitlement of any conceivable point.

A situation in which citizens' entitlements are controlled exclusively by public officials is one in which each citizen's entitlements are exercised or waived on the basis of collective goals, or on the basis of aggregated beliefs about individual welfare. Whether or not officials openly exercise their powers over individual entitlements in line with proclaimed or established goals and policies (such as the aggressive pursuit of tort-feasors or a hardlines approach to personal accidents), or whether they genuinely try to exercise those powers in the interest of the individuals concerned, the reality will be that powers of enforcement and waiver will be exercised according to established rules and guidelines which regulate their application. Where officials are charged with controlling the entitlements of large numbers of people, the growth of a body of general rules delineating the exercise of legal powers is inevitable. Particularly in societies which have evolved a doctrine of stare decisis, the growth of a body of jurisprudence around attempts to apply powers on a case-by-case basis will seem the only means (aside from explicitly posited rules) by which officials can approach their task in a comprehensible and even-handed way. The growth of a body of jurisprudential principles will represent the expression of shared ideas (perhaps only among the public officials) about how each individual's interests should be ordered and protected. Though each case will throw up distinctive questions, departures from received or established ideas will require separate justification which will itself contribute to the jurisprudential understanding of how individual rights are to be enforced.

Where the enforcement or waiver of a person's legal advantages depends upon general public rules, there will be no obvious way of drawing the boundary between public and private goals. For each person's interests will be given legal effect just to the extent that they contribute to broad public ideas about how an individual's relationships should be conducted. Suppose John contracts with Mary for the supply of 600 industrial widgets to be delivered by a specified date. Where powers of enforcement and waiver lie exclusively in the hands of public officials, what sense would attach to the claim that John or Mary have entitlements under the contract? If Mary fails to deliver by the due date, causing John to incur considerable loss, John's ability to recover would lie entirely within the purview of officials who have the power to decide whether or not to institute legal proceedings. If officials openly decide issues of enforcement or waiver in the light of broad social aims, John's role in litigation is likely to be confined to drawing purported breaches of right to official attention: for to ascribe any role to the plaintiff in the presentation of claims and arguments before the court would be to invest in individuals a considerable level of residual control over the terms in which their claims are presented. ${ }^{64}$ Having been granted official leave to make a

64 Such control might equally, if less directly, be manifested in the instructions given by the plaintiff to his legal representative, who both advises and acts on the basis of his client's instructions. See above for further consideration of this point in relation to legally incompetent right-holders. 
claim, those individuals would then exercise effective powers of waiver and enforcement through legal argumentation, by emphasising particular aspects of a claim and by downplaying or conceding others.

A state would have powerful reasons for placing such controls in private hands; but the result would be a straightforward collapse of the empire of interests into the republic of choice: ${ }^{65}$ public powers of 'waiver' would amount to little more than a body of doctrinal rules establishing the parameters of permitted action and outlining clear principles of breach of contract, duty of care and the like. The need for official decision regarding the desirability of legal proceedings can then be seen as constituting a form of pre-trial hearing, for the purpose of deciding whether there is genuinely a case to answer in law. A formal requirement of this kind would mark a curious procedural feature of the common law, but would not have much effect on the internal logic of legal pleading: each citizen would still exercise effective control over her range of legal entitlements within the scope of legal rules and regulations. John would have to convince the relevant officials that his claim falls within certain principles and definitions; but thereafter his position as a litigant would not significantly differ from that of a plaintiff at common law. The converse of this situation - where citizens lack any such control - is therefore marked by official control of every stage of legal pleading. Such a situation could only conceivably represent the desire to subject all private enterprise to extensive regulation in the light of collective assumptions about the common good. It is not obvious what evaluative point is served by retaining a reference to 'rights' in these circumstances except to draw attention to the fact that each person's interests are heavily regulated as part of some amalgamated political ideal. ${ }^{66}$

\section{Conclusion}

The circumstances of modern political and legal thought in the Western world have propelled the notion of a right into the centre of our social concerns and understandings. This is not an altogether happy situation, but one which is inevitable as long as we continue to view the social world

65 See L. Friedman, The Republic of Choice: Law, Authority and Culture (Cambridge Mass., Harvard University Press 1990).

66 Suppose someone objected to this conclusion on the ground that officials could in fact seek to waive or enforce duties exclusively on the basis of the interests of the individuals concerned, in the light of the facts of each case. Legal advantages possessed by those individuals would then (it might be claimed) enjoy adequate protection whilst acting as markers of private interests distinct from wider collective projects. Two responses are in order: first, it is hard to see how the exercise of official powers is compatible with any meaningful distinction between public and private interests. If official decisions about enforcement/waiver are indeed taken outside the scope of fixed rules (which is doubtful), then legal proceedings undertaken by those officials would simply resemble attempts at arbitration within an adjudicative framework rather than the genuine enforcement of legal rights. Secondly, forms of social order might emerge as abstract possibilities without constituting plausible political realities. Aside from the fact that any such regime would be administratively inconceivable, the point of transferring the responsibility for presenting claims and arguments of fact to public officials in this way escapes rational comprehension if the desire really is to protect individual interests quite apart from collective ideals. 
through 'Protestant' eyes. Given the irresolvable tensions of a shared social life, it is in the notion of protected choices that we best reflect and give expression to the liberal ideals which underpin the Protestant political order: for the presence of private domains of autonomous decision is both the defining feature of the modern political order and the source of its most pressing problems. The Will and Interest theories of rights can be represented as opposing solutions to the problem of clashing interests. The Interest theory, I have suggested, should be read as the attempt to find some shared moral perspective against which each person's interests can be balanced out or reconciled; but the pervasive disagreements which attach to the articulation of individual interests forces the Interest theorist to seek moral agreement at the level of highly abstract and generalised political visions. Accordingly, the Interest theory is closely associated with forms of moral idealism which ultimately undermine a commitment to the liberal values which define the modern political landscape.

The Will theory, by contrast, attempts to locate private disagreements about the political good within a context of established rules and principles which simultaneously empower individuals to make meaningful decisions about their relationships with other people, and regulate those decisions. The reality of a private sphere within which individuals are free to formulate and pursue their own aims depends upon a body of rules and standards which are relatively immune from revision in the light of sweeping political interpretations. It is thus in preserving and clarifying the boundaries between entitlement and regulation that the significance of rights for the liberal polity is most powerfully explained. 